\title{
OPTIMIZATION OF GUAVA JUICE AND POWDER PRODUCTION
}

\author{
CHETAN A. CHOPDA and DIANE M. BARRETT ${ }^{1}$ \\ Department of Food Science and Technology \\ University of California, Davis \\ Davis, CA 95616-8589
}

Accepted for Publication November 15, 2001

\begin{abstract}
Enzyme treatment of guava puree was optimized for yield and clarity by first determining the most effective concentration, then varying both incubation time and temperature. Application of Pectinex Ultra SP-L was optimal using 700 ppm enzyme for $1.5 \mathrm{~h}$ at 50C. Clarified guava juice was clearer (89.6\%) when prepared using ultrafiltration (MW cut-off 40-60 $\mathrm{kDa}$ ) rather than plate and frame filtration (82.8\%); however, the latter was higher in both soluble solids and ascorbic acid. Clarified guava juice powders were made using freeze-drying, spray drying and tunnel drying. The freeze-dried product had superior quality; however, the spray-dried product was stable and may be more economical. Sensory panelists ranked the cloudy juice prepared from aseptic guava puree highest, and there were no significant differences between the juices from pasteurized, clear nectar, freeze-dried puree powder or juice powder.
\end{abstract}

\section{INTRODUCTION}

Guava (Psidium guajava L.), which belongs to the Myrtaceae family, is a native of tropical America and grows well in tropical and subtropical regions. Guava fruit has a characteristic flavor, to which its acidity ( $\mathrm{pH} 4.0$ to 5.2) contributes (Jagtiani et al. 1988). It is a rich source of ascorbic acid, containing over $100 \mathrm{mg} / 100 \mathrm{~g}$ (Wenkam and Miller 1965). Most of the guava produced around the world is consumed fresh. Marketing of processed products such as puree, paste, canned slices in syrup or nectar is limited (Jagtiani et al. 1988). Clarified and cloudy guava juices are currently produced and may have greater market potential, but optimal process conditions for these products have not been determined.

1 Send correspondence to: Dr. Diane M. Barrett, University of California, Davis, One Shields Avenue, Davis, CA 95616-8589. TEL: (530) 752-4800; FAX: (530) 754-7677; E-mail: dmbarrett@ucdavis.edu 
The use of enzymes to maximize the yield of cloudy juice and promote clarification is uncommon in the production of guava juice. Commercial preparations containing pectinases, arabinase and cellulase may benefit guava juice production. Pectinase assists in pectin hydrolysis, which causes a reduction in pulp viscosity and a significant increase in juice yield. Pectin methyl esterase (PME) and polygalacturonase (PG) are pectinases which release carboxylic acids and galacturonic acid during enzyme treatment, which may lead to a decrease in the pulp pH (El-Zoghbi et al. 1992). Arabinase and cellulase convert araban and cellulose to soluble sugars that increase the soluble solids (SS). Arabinase also assists in eliminating the turbidity of juice caused by araban, which is visible only after 3-4 weeks of storage. There is an increase in the ascorbic acid content of guava juice following enzyme treatment due to release from the peel, which is a rich source (Askar et al. 1992).

Yield of cloudy juice is significantly affected by the temperature and time used for enzyme treatments. Increasing exposure time elevates yield but also causes a reduction in ascorbic acid content of the juice due to oxidation (Imungi et al. 1980). Immature fruits have a higher percentage of phenolics, which may affect the clarification process by preventing the settling of suspended solids or by hindering the activity of the enzymes used for extraction. Therefore, selection of fully ripe, firm yellow fruit without bruises is essential for processing.

A significant portion of the population prefers a grit-free, clear, haze-free guava juice. Clarified guava juice may be more acceptable to the general population, and may be used in the manufacturing of clear guava nectar or jelly, clear guava powder or a mixed fruit juice blend. There is also potential for use of an instant guava powder in formulated drinks, baby foods and other products. Transportation costs would be reduced significantly when shipping this product to distant markets. However, information about guava powders does not exist in the literature. Guava has delicate color and flavor properties and drying operations must be carefully designed to maintain these.

Several methods may be used for production of guava powder, but the most successful include freeze-drying, foam mat drying, spray drying and tunnel drying. Researchers have successfully used freeze drying to convert guava products into powder although freeze drying is known to be the most expensive method of drying. Very little literature is available on spray drying of guava products, but Muralikrishna et al. (1968) have reported difficulties in spray drying guava pulp. Maltodextrin products may serve as carriers and facilitate drying. Tunnel drying is well known to be the cheapest method of drying an acceptable quality powder.

The first objective of this study was to select the correct enzyme dosage and optimum treatment time and temperature for maximizing yield of cloudy juice and retaining ascorbic acid. At the same time, the cost effectiveness of the enzymes utilized was also of interest. A second objective was to evaluate the 
effect of both ultrafiltration and plate and frame filtration on the flux, turbidity, ascorbic acid retention and soluble solids (SS) content of clarified guava juice. The third objective was to prepare guava powders using freeze drying, spray drying and tunnel drying methods and evaluate the effects of drying on physico-chemical properties. A consumer preference test was conducted to determine the sensory quality of these clarified juice, cloudy juice and reconstituted juice products, and to compare products to those available in the market.

\section{MATERIALS AND METHODS}

\section{Raw Materials}

Guava puree made from the white fleshed variety 'Allahabad safeda,' manufactured by Enkay Texofood Industries Limited (Valsad, Gujrat, India), was obtained in aseptically packed $20 \mathrm{~kg}$ bag-in-box containers. Pectinex Ultra SP-L enzyme was obtained from Novo Nordisk Biochem North America Inc. (Franklinton, NJ) and ADM DMG 70 ${ }^{\circ}$, a distilled monoglyceride, was obtained from Archer Daniels Midland Company (Decatur, IL). Three maltodextrin products, Maltrin $100^{\circ}$, Maltrin $500^{\circ}$ and Maltrin $580^{\circ}$, and modified food starch powders Pure-cote $B 760^{\circ}$ and Pure-cote $B 790^{\circ}$ were obtained from the Grain Processing Corporation (Muscative, IA). Commercially manufactured (Nestle, Glendale, CA) cloudy pink guava nectar containing $18 \%$ juice was procured locally.

Laboratory reagents such as iodine, phenolphthalein, potassium iodide, metaphosphoric acid and the sodium salt of 2,6-dichlorophenol-indophenol were obtained from Sigma Chemical Company (St. Louis, MO). L-ascorbic acid, hydrochloric acid and sodium hydroxide were obtained from Fisher Scientific Company (Fair Lawn, NJ). Distilled deionized (DI) water was used in all experiments.

\section{Processing}

Enzyme Treatment. Processing conditions are outlined in Fig. 1. Enzyme treatment conditions were optimized in the laboratory prior to carrying out treatment at the pilot scale. Four hundred ppm of Pectinex Ultra SP-L were added to guava puree in a Julabo $20 \mathrm{~B}$ (Seelbach, Germany) water bath at five different temperatures, i.e. $35,40,45,50$ and $55 \mathrm{C}$. The optimum temperature for enzyme treatment was evaluated after incubation for $1 \mathrm{~h}$ and this temperature was used to estimate the optimum time and concentration for enzyme treatment. Guava puree was mixed with 300,500 and 700 ppm Pectinex Ultra SP-L, and samples were removed at every $1,1.5,2$ and $2.5 \mathrm{~h}$ time interval. Part of this 
enzyme treated puree was immediately frozen using liquid nitrogen and stored at $-80 \mathrm{C}$ for ascorbic acid analysis. The remainder was heated to $80 \mathrm{C}$ for $30 \mathrm{~s}$ to inactivate the commercial enzyme using a Cole Parmer hot plate (Model 51450 series, Vernon Hills, IL); this was used for other analytical measurements. All experiments were carried out in duplicate.

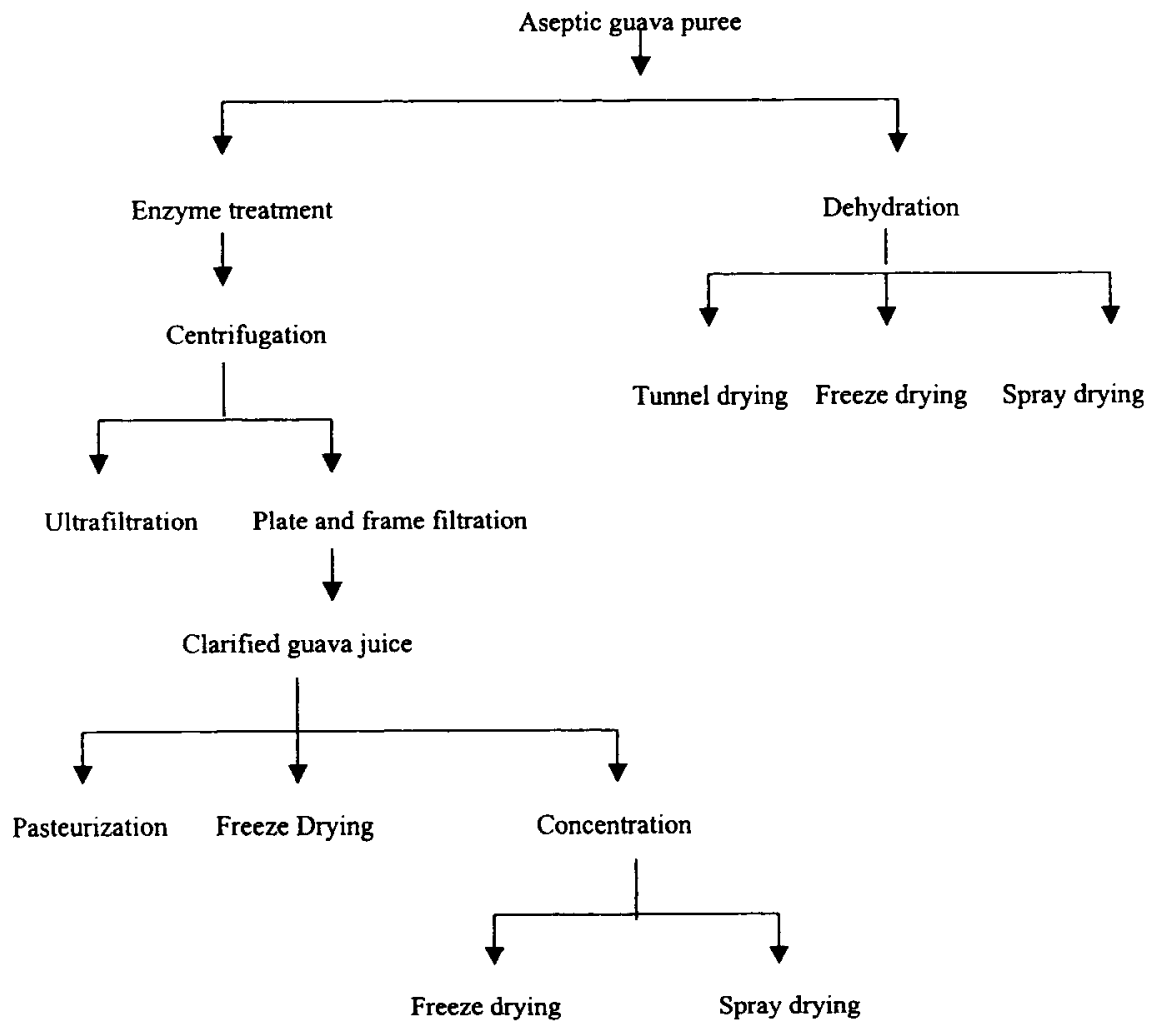

FIG. 1. FLOW DIAGRAM OF GUAVA PUREE PROCESSING 
After determining the optimal process parameters in the laboratory, enzyme treatment was conducted in the Food Processing Laboratory of the Department of Food Science and Technology, using a $500 \mathrm{~L}$ steam jacketed vessel. To avoid further enzymatic hydrolysis, the enzyme treated puree was immediately stored at $4 \mathrm{C}$ for no more than $12 \mathrm{~h}$ until further processing.

Centrifugation. The enzyme treated puree was centrifuged at $10,410 \times \mathrm{g}$ $(8,000 \mathrm{rpm})$ for $8 \mathrm{~min}$ at $4-8 \mathrm{C}$ in a RC-5C Model centrifuge from Sorvall Instruments, Dupont (Wilmington, DE), to remove the suspended material and aid in juice clarification. After centrifugation, the supernatant was filtered through cheesecloth and stored at $4 \mathrm{C}$ for no more than $24 \mathrm{~h}$ until further processing. Centrifuged samples were filtered using either plate and frame or ultrafiltration.

Ultrafiltration. A SEPA ${ }^{\circledR}$ CF membrane cell, manufactured by Osmonics Inc. (Minnetonka, MN), was used to ultrafilter the centrifuged puree. The cell consisted of a RZ04 (molecular weight cut-off 40-60 kDa) membrane and an Enerpac hydraulic hand pump (Butler, WI) and operated under a pressure gradient of $250 \mathrm{psi}$. Feed material was recirculated through the system until a substantial reduction in permeate flux was observed.

Plate and Frame Filtration. The centrifuged juice was also clarified using a pilot scale plate and frame filtration unit and Micro-Media filter pads manufactured by Ertel Engineering Co. (Kingston, NY). Three filter pad grades M50 (retention $1 \mu$ ), M80 (retention $0.5 \mu$ ) and M90 (retention $0.25 \mu$ ) were compared and the system operated at a pressure of 15-20 psi. The clarified juice was stored at $4 \mathrm{C}$ for no more than $48 \mathrm{~h}$ until further processing.

Pasteurization. Clarified juice was pasteurized using a plate heat exchanger (APV Model JRHE, Buffalo, NY). Juice was heated to 93C and held for $48 \mathrm{~s}$. One-gallon glass bottles were pre-sterilized in an autoclave and hot filled, followed by capping and inverting the bottle for $45 \mathrm{~s}$ to sterilize the lid. After cooling, bottles were stored at $4 \mathrm{C}$ for 7 weeks before they were used in the final sensory test.

Concentration. Clarified guava juice was concentrated to $42^{\circ}$ Brix using a 12 in. wiped film evaporator (Pfaudler Permutt Inc., Rochester, NY). Concentration was carried out at $146 \mathrm{C}$ for $90 \mathrm{~s}$ under vacuum.

Freeze Drying. Aseptic puree, clarified juice and clarified juice concentrate were freeze dried in a VIRTIS Model 50 SRC 5 (Gardiner, NY) freeze dryer. An approximately $1.5 \mathrm{~cm}$ thick, layer was placed on each tray and frozen 
overnight at $-25 \mathrm{C}$; then the heating plate temperature was set to $46 \mathrm{C}$ and the vacuum to $55 \mathrm{mT}$ Trr to initiate drying. After drying for $48 \mathrm{~h}$, blocks of guava powder were removed from trays and ground in a heavy-duty food grinder (Oster, Mexico) and the fine powder was stored in plastic containers at room temperature.

Spray Drying. Guava juice concentrate and diluted aseptic guava puree were spray dried using an APV Anhydro A/S laboratory size no. 1 spray dryer (Attleboro, MA). A Bosch 1210 type atomizer (Scintilla SA, Switzerland) with the atomizer speed regulator set at 220 volts was utilized. The inlet temperature of the feed material was set to $160 \mathrm{C}$ by adjusting the power supply with a $5 \mathrm{~kW}$ heating element. The outlet (product) temperature was set to $80 \mathrm{C}$ by regulating the feed pump speed. Powder was separated from hot air by a cyclone separator and stored at room temperature. Three different maltodextrin products, Maltrin $100^{\circ}$, Maitrin $500^{\circ}$ and Maltrin $580^{\circ}$, were added to the samples prior to spray drying. Based on the formula developed for spray drying an orange juice mix (Kramer 1998), the following combinations were selected and blended using a hand mixer prior to drying:

(1) $300 \mathrm{~g}$ clear juice concentrate $+285 \mathrm{~g}$ Maltrin $100^{\circ}$

(2) 300 g clear juice concentrate $+285 \mathrm{~g}$ Maltrin $500^{\circ}$

(3) 3000 g $4.7^{\circ}$ Brix puree +249 g Maltrin $580^{\circ}+48 \mathrm{~g}$ Maltrin $100^{\circ}+13$ g Maltrin $500^{\circ}$

Tunnel Drying. Puree was mixed with the following ingredients and placed on separate trays:
(1) $117.1 \mathrm{~g}(20 \%)$ Pure-cote $\mathrm{B} 790^{\circledR}+585.5 \mathrm{~g}$ of puree $+146.38 \mathrm{~g}(25 \%)$ sugar
(2) $130 \mathrm{~g}(20 \%)$ Maltrin $580+650 \mathrm{~g}$ puree $+162.5 \mathrm{~g}$ sugar $(25 \%)$
(3) $117.1 \mathrm{~g} \mathrm{(20 \% )} \mathrm{Pure-cote} B 760^{\circ}+585.5 \mathrm{~g}$ puree $+146.38 \mathrm{~g}(25 \%)$ sugar

Pure-cote and Maltrin provide flexible film-forming and adhesive properties to the puree. Concentrations of these ingredients were selected based on recommendations by the Grain Processing Corp. (1998). Sugar was added to improve retention of color and flavor and to improve drying characteristics of the final product (Askar et al. 1992).

The tunnel dryer was a batch type and air temperature was maintained by a steam control system (Foxboro, MA). A thin layer of each solution was spread on cheesecloth and placed over a wire mesh tray, which was placed in the tunnel dryer for drying. The air temperature which flowed parallel to the breadth of the trays was set at $70 \mathrm{C}$ for the first $2 \mathrm{~h}$ of drying, then was reduced to $60 \mathrm{C}$. After 
drying was complete, at approximately $12 \mathrm{~h}$ as judged by the appearance, flakes of dried guava puree were collected and stored at room temperature.

\section{Analytical Methods}

All analytical measurements were carried out in duplicate.

Total ascorbic acid, moisture content and total titratable acidity were determined according to the methods described by Askar $e t$ al. (1992). Total ascorbic acid was calculated titrimetrically using the sodium salt of 2,6-dichlorophenol-indophenol. Moisture content (\% moisture $w / w$ ) was measured using a vacuum oven (Hythermco, Model 6002, Hydor Therme Corporation, Pennsauken, NJ), which operated at $100 \mathrm{C}$ and 26 in. of $\mathrm{Hg}$ pressure. The $\mathrm{pH}$ was measured using a Beckman Zeromatic SS-3 (Fullerton, CA) pH meter, along with an Orion glass electrode (Model \# 91-03, Boston, MA). Powder samples were evaluated for $\mathrm{pH}$ by mixing $10 \mathrm{~g}$ powder with $50 \mathrm{~g}$ DI water at $18 \mathrm{C}$. Measurement of total titratable acidity was conducted using a standard $1 \%$ phenolphthelein solution, titrated against $0.1 \mathrm{~N} \mathrm{NaOH}$ to $\mathrm{pH} 8.1$; the result was expressed as grams of anhydrous citric acid per $100 \mathrm{~g}$ of sample. Degrees Brix was measured using an RFM 80 digital refractometer (Bellingham Stanley Ltd., England) with automatic temperature correction. Ten grams of powder were mixed with $50 \mathrm{~g}$ deionized (DI) water and this solution was filtered, if necessary.

The color of the puree, juice and powder samples was measured using a Minolta colorimeter, Model CR-200 (Ramsey, NJ) and expressed as L*, $\mathrm{a}^{*}$ and $\mathrm{b}^{*}$ values. Pectin was detected according to the qualitative method suggested by Novo Nordisk (1998). The $10 \mathrm{~mL}$ of acidified ethanol $(1 \mathrm{~mL}$ of $37 \% \mathrm{HCl}$ in $100 \mathrm{~mL}$ of $96 \%$ ethanol) was mixed with $5 \mathrm{~mL}$ of filtered puree and after slowly inverting the tube 2 or 3 times, the nature of flocculation was observed after 15 min. Percent yield $(w / w)$ was calculated by weighing the supernatant obtained by centrifuging the enzyme treated puree. The presence of starch was tested by the iodine test (Novo Nordisk 1998), for which an iodine solution was prepared by adding $1 \mathrm{~mL}$ iodine and $10 \mathrm{~g}$ potassium iodide to $1 \mathrm{~L}$ water. $\mathrm{A} 10 \mathrm{~mL}$ sample was heated to above $80 \mathrm{C}$ and cooled to room temperature. One milliliter of iodine solution was gently poured over the top layer of the sample without mixing and the color change at the interface was observed. Turbidity (clarity) was measured using the percent transmission mode in the Shimadzu UV-VIS scanning spectrophotometer (Model \# UV-2101 PC, Kyoto, Japan) (Chan and Chiang 1992). Viscosity was measured with a Brookfield viscometer (Model LVT, Stoughton, MA) using spindles \#2 and \#3 (Askar et al. 1992).

Juice and powder samples were analyzed for aerobic plate count (APC) and yeast and mold counts. All microbial tests were conducted by Silliker Laboratories (Modesto, CA). Plate count agar was used for the APC with $10^{-2}-10^{-4}-10^{-6}$ 
serial dilutions, and potato dextrose agar along with an antibiotic additive was used for yeast and mold count analysis with $10^{-1}-10^{-2}-10^{-4}$ dilutions.

\section{Sensory Analysis}

The optimum dilution for each juice sample was first determined in informal sensory tests. Preference ranking tests were conducted for both the preliminary and final sensory tests, using a consumer panel. For all the juice samples, the final ${ }^{\circ}$ Brix was adjusted to $11^{\circ}$ using cane sugar. Eight to ten responses were collected for each preliminary sensory test. Fifty milliliters of juice (5-8C) was served and five juice concentrations were presented during each serving. Final sensory tests were conducted in sensory booths with controlled illumination. For these tests, 45 responses were collected, and the serving order was determined using the balanced-block design suggested by Stone and Sidel (1993). In the second half of each test, commercial cloudy pink guava nectar containing $18 \%$ juice (Nestle, Glendale, CA) was presented and consumer panelists were asked to compare it with their most preferred sample.

\section{Statistical Analysis}

All processing experiments and analysis of the samples were run in duplicate. Analysis of variance was calculated using the standard ANOVA procedure. Sensory ranking data was analyzed using the Basker Table and the Friedman test (Lawless and Heymann 1998). All data were analyzed at a 5\% probability level. Significant differences between the means were estimated using Duncan's multiple range tests.

\section{RESULTS AND DISCUSSION}

\section{Enzyme Treatment Optimization}

Of the five temperatures evaluated, the $50 \mathrm{C}$ incubation temperature yielded the maximum ${ }^{\circ} \mathrm{Brix}$, ascorbic acid content, percentage yield and titratable acidity in the enzyme treated puree without resulting in a significant loss in guava flavor. The same temperature and enzyme were used by Hodgson et al. (1990) however, El-Zoghbi et al. (1992) found the highest activity of this enzyme at an incubation temperature of $40 \mathrm{C}$.

As enzyme concentration and incubation time increased, a gradual increase in ${ }^{\circ}$ Brix and titratable acidity observed along with a decrease in $\mathrm{pH}$ and viscosity (Table 1). Similar results were obtained by Imungi et al. (1980), Askar et al. (1992) and Brasil et al. (1995). The main criteria for optimizing concentration and incubation time were viscosity reduction, percent yield and 


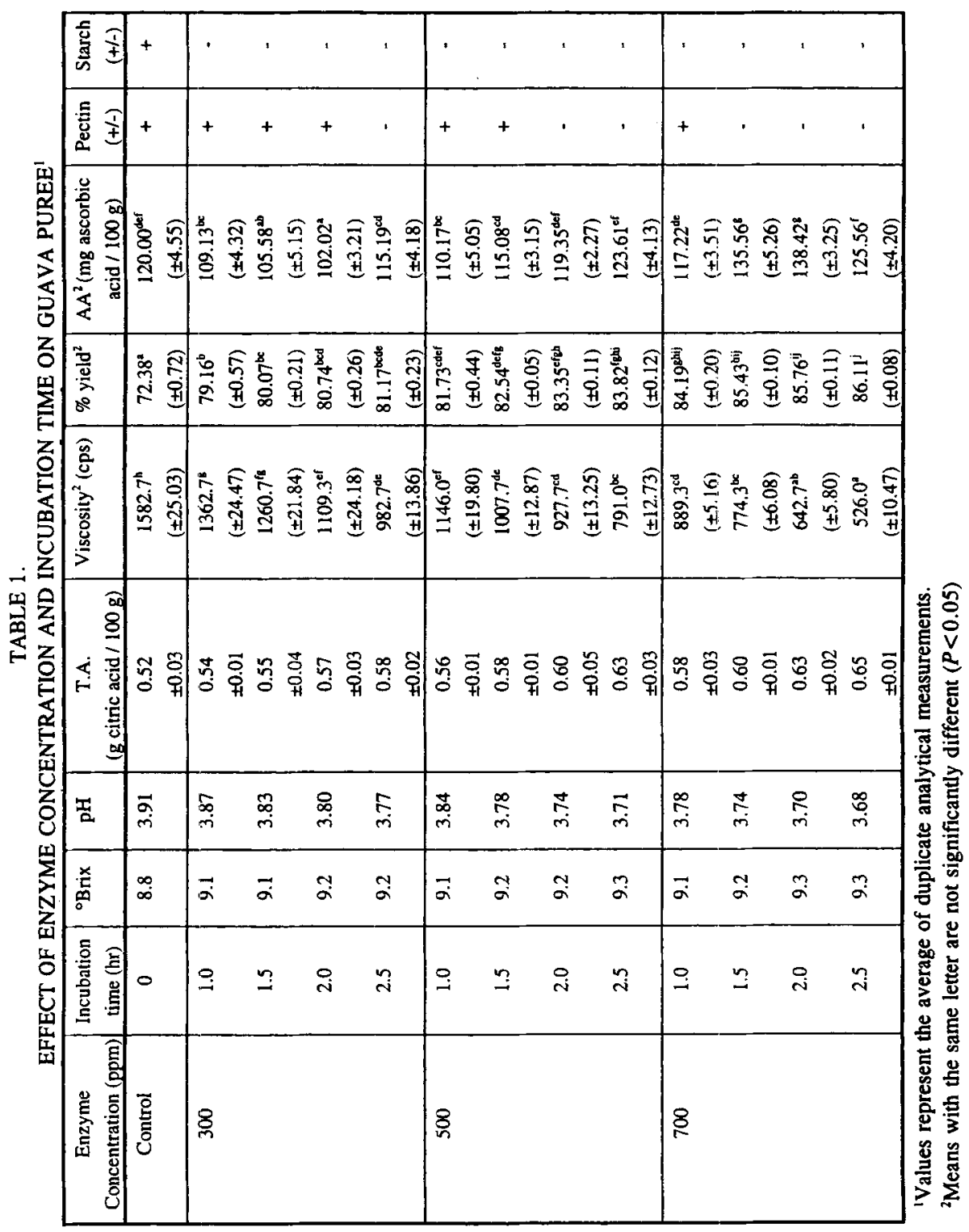


ascorbic acid retention in the puree. Reduction of viscosity aids in the formation of fine spray during concentration and spray drying. Significantly higher yields of clarified juice were obtained using $700 \mathrm{ppm}$ enzyme for $1.5 \mathrm{~h}$ (Table 1). When the control sample was centrifuged, it produced a cloudy supernatant while enzyme-treated puree produced a clear juice. Except for samples treated with $500 \mathrm{ppm}$ enzyme at $2.5 \mathrm{~h}$ and $700 \mathrm{ppm}$ at 1.5 and $2 \mathrm{~h}$, the ascorbic acid content in all samples was less than that in the control. In these samples, ascorbic acid was released from cells due to pectin breakdown, however simultaneous oxidative degradation of ascorbic acid exceeded its rate of release. In the exceptional concentrations stated above, the situation was reversed. All enzyme treatments resulted in a negative starch test, indicating a lower initial starch content in the puree.

An enzyme treatment of $700 \mathrm{ppm}$ concentration for $1.5 \mathrm{~h}$ was determined to be the most efficient and economical. A cost comparison showed that enzyme treatment at $300 \mathrm{ppm}$ concentration for $1 \mathrm{~h}$ resulted in $78.5 \%$ recovery of input cost as compared to an $83.9 \%$ recovery from a $700 \mathrm{ppm}$ treatment for $1.5 \mathrm{~h}$. The latter was sufficient to degrade pectin and starch completely and to obtain very high ascorbic acid retention. Ascorbic acid retention, percent yield and viscosity values from the $700 \mathrm{ppm}$ treatment for $2 \mathrm{~h}$ were not significantly different $(P<0.05)$ from those treated $1.5 \mathrm{~h}$. Therefore, a treatment of $700 \mathrm{ppm}$ for $1.5 \mathrm{~h}$ was selected to minimize the cost, processing time and potential flavor losses during incubation.

Hodgson et al. (1990) selected an enzyme treatment of $0.2 \%$ w/w $(2000$ ppm) Pectinex Ultra SP-L for $2 \mathrm{~h}$. Imungi et al. (1980), reported a treatment of $400 \mathrm{ppm}$ of Pectinex (Ferment Ltd., Switzerland) for $1.5 \mathrm{~h}$; Brasil et al. (1995) selected $600 \mathrm{ppm}$ of Clarex-L superconcentrate (Miles-Brasil Ltd., Brazil) for $2 \mathrm{~h}$ and Askar et al. (1992) used a treatment of $400 \mathrm{ppm}$ Ultrazyme $100^{\circ}$ (Ciba Giegy Ltd. Switzerland) for $2 \mathrm{~h}$. In all cases, either enzyme concentration or incubation period was determined first, with the remaining factor determined experimentally. The current study is the first in which a complete study of incubation time and enzyme concentration was performed.

If higher enzyme concentrations are utilized, the increased enzyme cost and significant losses in ascorbic acid content may not justify the increased yield of guava juice. The optimized enzyme treatment was found to be very economical. In this treatment, $\$ 18.55$ worth of enzyme applied to 1 ton of guava puree resulted in an increase in juice production worth $\$ 132.10$.

\section{Clear Juice and Concentrate Production}

Centrifugation removed most of the insoluble particles from the puree, but there remained some colloidal particles that caused turbidity in the juice. This turbidity was effectively removed by filtration either through the plate and frame 
filter or ultrafiltration (UF). In plate and frame filtration, ${ }^{\circ}$ Brix and percent transmission results indicated that a fraction of the soluble solids and a majority of the substances responsible for turbidity in the centrifuged puree lie within the $0.5 \mu$ and $0.25 \mu$ particle size range. Moreover, it was observed that the smallest pore size filter pads (M90, $0.25 \mu$ ) did not completely remove the color of the juice. Chan and Chiang (1992) found optimum clarity (85\% transmission at $650 \mathrm{~nm}$ ) after treating puree with pectinase and holding the $30 \%$ puree solution with $2000 \mathrm{ppm}$ bentonite for $10 \mathrm{~min}$. The M80 filter pads were sufficient to achieve clarity in the guava juice (83\% transmission) similar to what was determined by Chan and Chiang (1992). UF juice was clearer with $90 \%$ transmission, as compared to $83 \%$ for plate and frame filtered juice.

The plate and frame filtered juice retained more soluble solids and contained $5.8 \%$ more ascorbic acid than the UF juice (Table 2). Greater loss in ascorbic acid with UF may have been due to higher temperature in the feed material and more oxidative losses during the turbulent flow through the system. During UF, concentration polarization on the membrane surface, which led to formation of a fouled layer, was responsible for a gradual decline in the permeate flux with time. Chan and Chiang (1992) and Constenla and Lozano (1997) found similar reductions in permeate flux during UF of centrifuged guava puree and apple juice, respectively. Based on the higher flux rates for plate and frame filtration at all times and sufficient clarity obtained using M80 filter pads, plate and frame was selected for pilot scale processing. However, on an industrial scale, ultrafiltration may be more economical, resulting in a superior clarified juice. Moreover, it can be used to cold-sterilize juice, eliminating the heat treatment step which causes a significant loss in sensitive flavor compounds.

High temperature and incorporation of oxygen in the plate heat exchanger were primarily responsible for the significant loss of ascorbic acid $(45 \%)$ in pasteurized juice (Table 2). The application of vacuum during heat treatment could improve ascorbic acid retention significantly. Brasil et al. (1995) also recorded an increase in the ${ }^{\circ} \mathrm{Brix}$ and color index during pasteurization, along with a $27.4 \%$ loss in ascorbic acid. Evaporation of water was responsible for an increase in SS content and a slight darkening of the juice.

After the clarified juice was concentrated, the following increases were found: 4.7 fold in ${ }^{\circ}$ Brix, 3.9 fold in titratable acidity and 4.2 fold in ascorbic acid content (Table 2). While concentrating their partially clarified guava juice, Hodgson et al. (1990) reported the following increases: 3.9 fold in ${ }^{\circ} \mathrm{Brix}, 4.03$ fold in titratable acidity and 4.18 fold in ascorbic acid content. In concentrating cloudy guava juice to $41^{\circ} \mathrm{Brix}$, Sandhu and Bhatia (1985) also reported these increases: 3.7 fold in ${ }^{\circ}$ Brix, 3.55 fold in titratable acidity and 3.5 fold in ascorbic acid content. Final ascorbic acid contents, as reported by Hodgson $e t$ al. (1990) and Sandhu and Bhatia (1985), were higher than those obtained in this study, e.g., $867 \mathrm{mg}$ and $849.82 \mathrm{mg}$ per $100 \mathrm{~g}$ concentrate, respectively. 


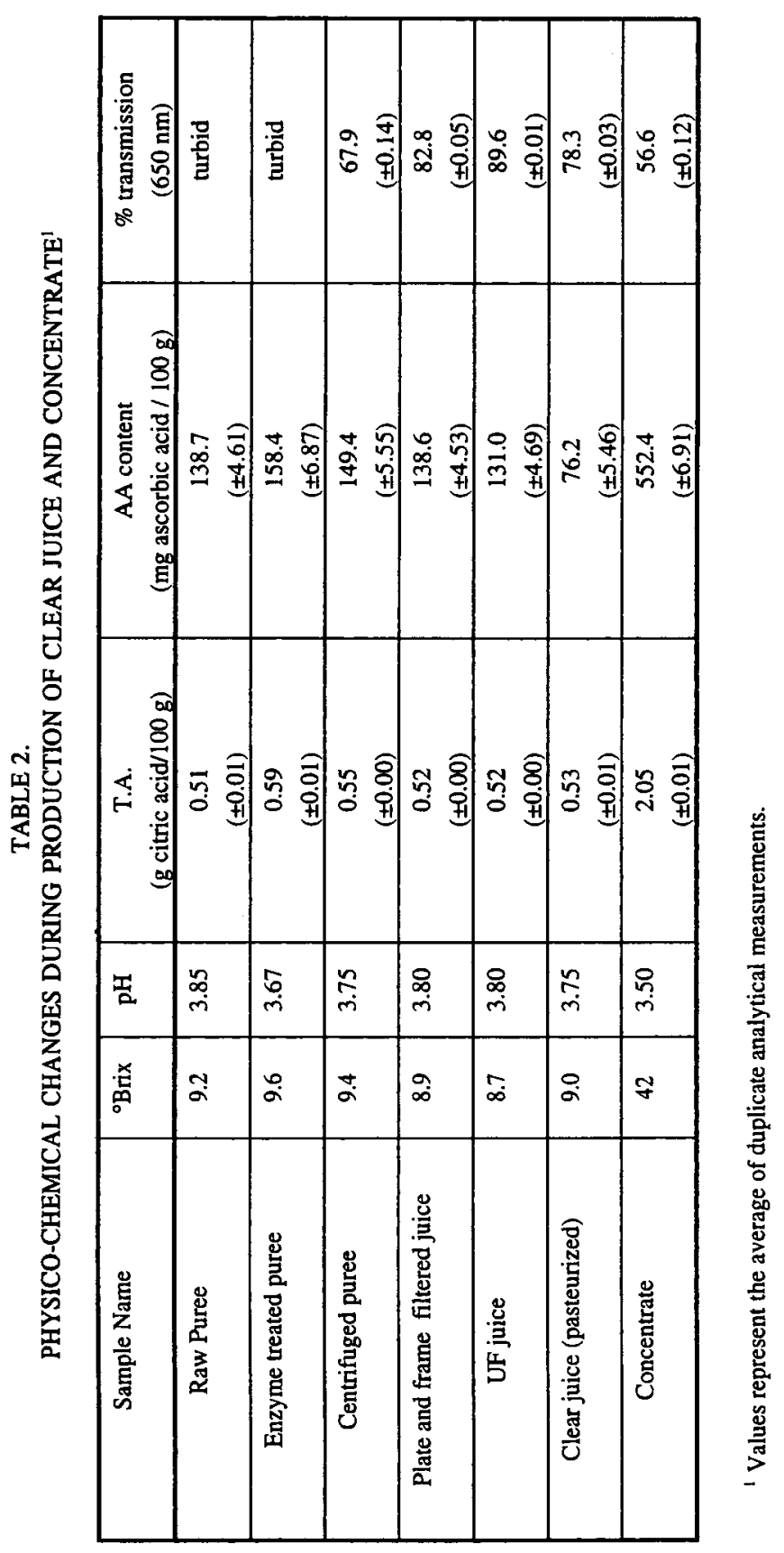


Although the juice was at a higher temperature for a longer time in the falling film evaporator as compared to the pasteurization process, less ascorbic acid deterioration was reported, primarily due to the use of vacuum and therefore avoidance of oxidative deterioration. Askar et al. (1992) reported a $30 \%$ loss in ascorbic acid after pasteurizing clear guava juice and a $60 \%$ loss after concentrating clear guava juice.

\section{Freeze Drying}

During freeze drying, rupture of cells in the guava puree may have induced the elution of cell contents, which caused an increase in SS content and titratable acidity and a reduction in the $\mathrm{pH}$ of the powder (Table 3). After freeze drying clear juice and concentrate, a reduction in the SS content was observed which may be due to a reduction in the amount of acids present in the feed material. A reduction in titratable acidity and an increase in the $\mathrm{pH}$ after freeze drying clear guava products indicates that acids were lost during the process. Askar $e t$ al. (1992) also reported a noticeable loss in total titratable acidity after freeze drying guava puree. The oxidative losses in ascorbic acid following freezedrying were approximately $12 \%$ in powder made from puree, $19 \%$ in clear juice powder and 15\% in concentrate powder. Askar et al. (1992) reported a 15\% loss of ascorbic acid when freeze drying pasteurized guava puree.

The increase in $\mathrm{L}^{*}$ (brightness), $\mathrm{a}^{*}$ (redness) and $\mathrm{b}^{*}$ (yellowness) values following production of guava puree powder (Table 3 ) was most likely a result of nonenzymatic browning during freeze drying, which produced a darker product. Askar et al. (1992) also obtained a darker freeze-dried pasteurized guava puree. Both powders produced from clear juice and concentrate were higher in $L^{*}$ value with lower $a^{*}$ and $b^{*}$ values, indicating a less intense color as compared to the original. The clear juice and concentrate were high in sugar and low in particulates, allowing for satisfactory puffing which was responsible for the lighter color and shiny nature of the powders. These powders were very hygroscopic in nature and powder removed from the trays was difficult to grind; whereas the puree powder was easy to grind and the least hygroscopic. To reduce the hygroscopicity of these powders, $0.5 \%$ sodium aluminosilicate can be added (Askar et al. 1992). All three powders were very porous in nature and could be reconstituted instantly with room temperature water. The reconstituted liquid prepared from clear juice powder was quite turbid ( $71 \%$ transmission), whereas that made from concentrate powder was clearer (82\% transmission). Soluble pectins in the clear juice may have aggregated during freeze drying and may be responsible for a slight turbidity in the reconstituted clear juice powder. 


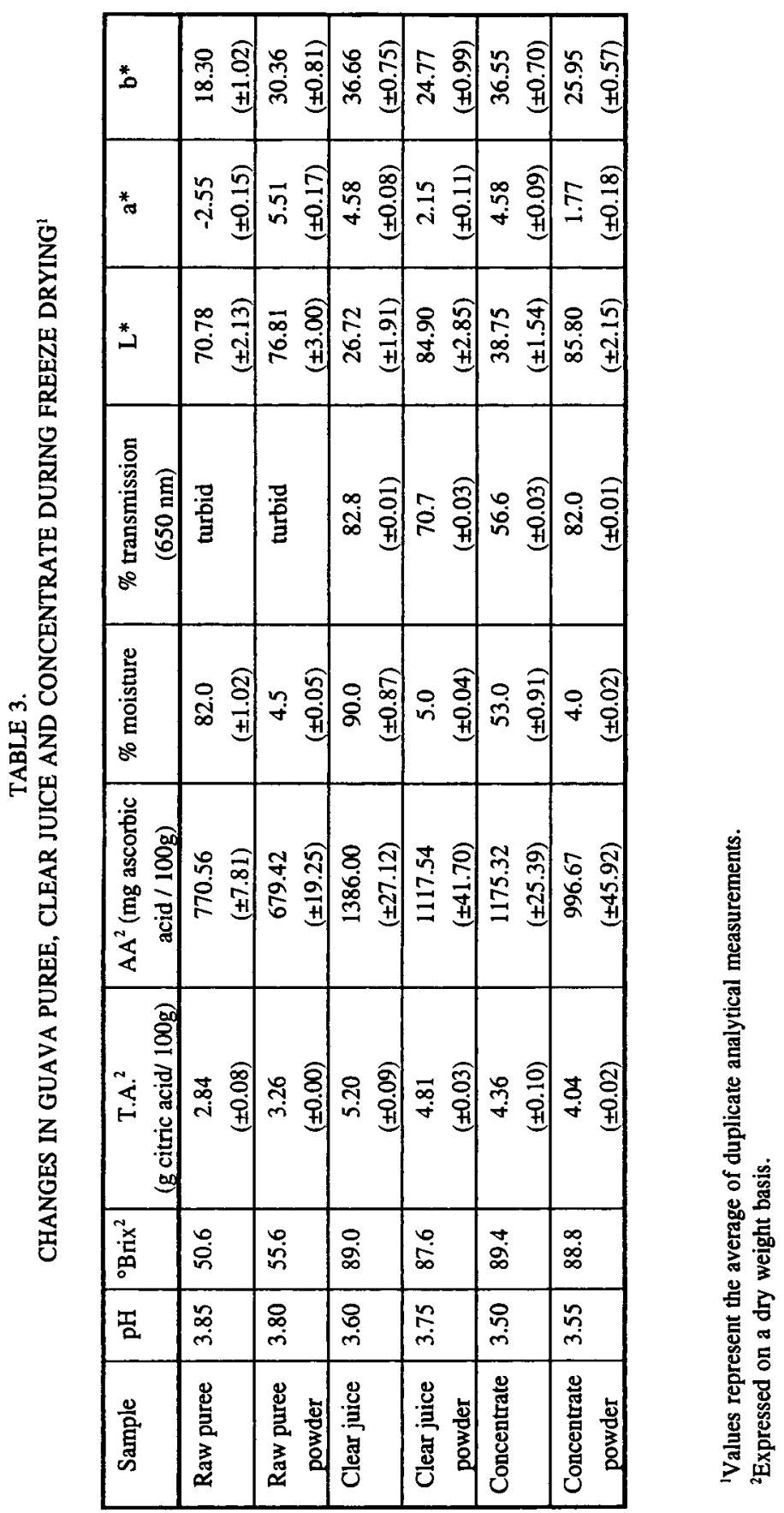




\section{Spray Drying}

During initial trials of spray drying clear juice, no powder was collected due to the low solids content of the feed. Therefore, the higher solids guava puree and guava juice concentrate were selected for spray drying. Spray drying was difficult due to high sucrose content and burn-on the equipment resulting from the high temperatures used. When Maltodextrin was added to the concentrate, it formed a film around the solids in the feed that facilitated production of a nonhygroscopic, free flowing, flour-like powder. All the powders produced by spray drying were bright white in appearance irrespective of the color of the feed material.

There was no significant difference $(P<0.05)$ between the $\mathrm{L} * \mathrm{a} * \mathrm{~b} *$ values for powders prepared using different maltodextrin products. Muralikrishna $e t$ al. (1969) reported production of a grayish white powder after spray drying guava puree without an additive. The spray-dried powders produced in this study were extremely stable at room temperature and could be reconstituted after blending with room temperature water. However, the reconstituted drinks made from concentrates were not clear, because the maltodextrin concentration exceeded the $30 \%$ solids limit suggested for making a clear solution (Grain Processing Corp. 1998).

The moisture content of all the spray-dried powders was lower than that of the freeze-dried powders (Table 4). Similar results were obtained by Muralikrishna et al. (1969) who had a final moisture content of $2.24 \%$ in the spray-dried powder. There was an increase in ${ }^{\circ}$ Brix and total titratable acidity and a decrease in $\mathrm{pH}$ following drying, which may be the result of concentration accompanied by release of sugars and acids from maltodextrin during drying. Ascorbic acid was lost during drying as a result of the high temperatures and oxidation. The average loss of ascorbic acid was around $21 \%$. Muralikrishna et al. (1969) found a similar loss of $19.1 \%$ ascorbic acid content in spray dried guava puree. Although M-100 and M-500 maltodextrin products are chemically the same, a better retention of ascorbic acid and soluble solids was observed with $\mathrm{M}-100$. The finer structure of $\mathrm{M}-100$ particles provided a more uniform coating of the feed solids during spray drying, giving better protection from thermal and oxidative losses than M-500.

\section{Tunnel Drying}

Tunnel drying is one of the least expensive methods of drying food materials. However, no literature is available on tunnel drying guava puree using any modified food starch or maltodextrin products. This drying method was very slow, requiring approximately $12 \mathrm{~h}$ to completely dry the product. During tunnel drying, a significant increase $(P<0.05)$ in titratable acidity and decrease in $\mathrm{pH}$ was noticed in all the powders (data not shown). There were no significant 


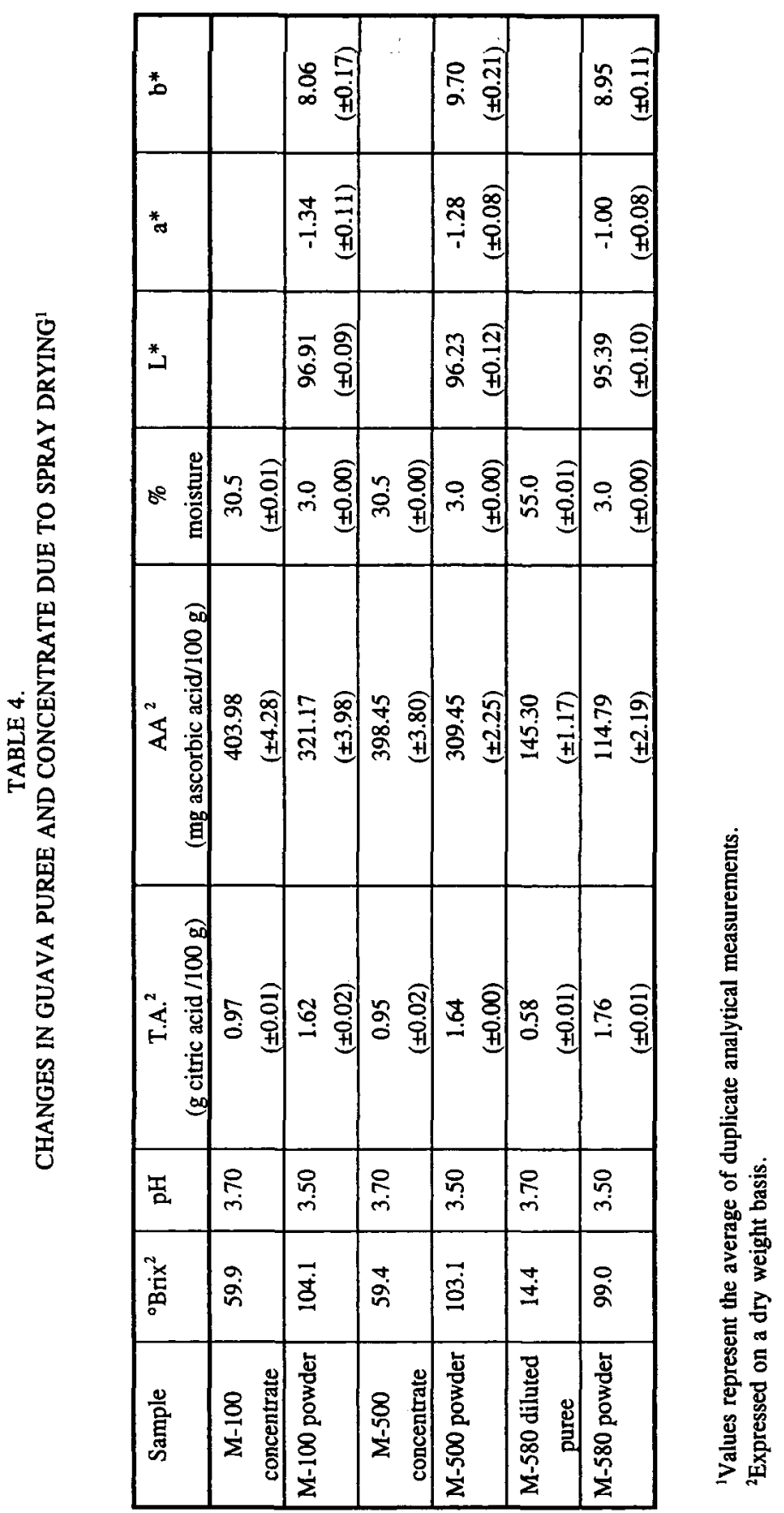


differences in ${ }^{\circ}$ Brix or titratable acidity of the powders that could be related to particular characteristics of the additives. After tunnel drying, the average loss of ascorbic acid was approximately $30 \%$, which was higher than freeze drying $(15 \%)$ or spray drying $(21 \%)$. Tunnel dried powder containing Maltrin $580^{\circ}$ maltodextrin was darker in appearance as compared to powders prepared using Pure-cote $\mathrm{B} 760^{\circ}$ and Pure-cote $\mathrm{B} 790^{\circ}$, which may be attributed to better coating provided by the maltodextrin product. All the powders were golden yellow in color, but were difficult to remove from the cheesecloth covering the drying trays and difficult to grind. Approximately $5 \mathrm{~min}$ were required to completely reconstitute with room temperature water.

\section{Microbiological Tests}

Freeze-dried concentrate powder had an Aerobic plate count (APC) of 5.3 $\times 10^{5} \mathrm{APC} / \mathrm{g}$ as compared to the spray-dried concentrate powder with $9.7 \times$ $10^{4} \mathrm{APC} / \mathrm{g}$, which could be attributed to the high temperatures achieved during spray drying. Spray-dried puree powder had relatively higher APC and yeast and mold counts as compared to the aseptic puree (e.g., $1.5 \times 10^{4}$ vs $1.5 \times 10^{2}$ $\mathrm{APC} / \mathrm{g}$ ). This may be due to the use of the M580 additive, which is reported to have a maximum standard plate count (SPC) of 100/g and a yeast and mold count of 50/g. Yeast and mold counts were relatively low in all samples and did not pose any threat to the safety of the drinks.

\section{Sensory Tests}

During the preliminary sensory tests for aseptic puree and pasteurized clear juice, concentrations of $35 \%$ and $55 \%$ (w/w) powder, respectively, were found to be optimum. This difference in concentration indicates the significant loss of flavor due to clarification. Spray-dried powder from puree was rejected because of a medicine-like off-flavor. This may be due to the addition of maltodextrin products at a higher concentration than desirable from a sensory standpoint.

Nectars were prepared by adding water and sugar to adjust to a final 11 ${ }^{\circ}$ Brix product. Commercial guava nectar containing $18 \%$ juice was an exception; its final ${ }^{\circ}$ Brix was $14.4^{\circ}$. Nectar made from freeze-dried clear juice contained the most ascorbic acid $(50 \mathrm{mg} / 100 \mathrm{~g})$, primarily due to the higher percentage of juice used in the final drink; whereas, the commercial nectar contained the least ascorbic acid $(10 \mathrm{mg} / 100 \mathrm{~g})$.

The majority of the sensory panelists (84\%) had tasted guava fruit or drink before, and $78 \%$ liked its taste. Most panelists preferred cloudy guava nectar, because they perceived it as a more natural product. Ranks assigned by each panelist were totaled for every sample and termed rank total (Table 5). Reference to the Basker table and the Friedman test (Lawless and Heyman 1998) showed no statistically significant difference $(P<0.05)$ between the rank totals 
of clear pasteurized nectar, nectar prepared from freeze-dried clear juice powder and puree powder. This indicated minimal flavor loss during freeze drying. Most panelists thought that the sweetness and flavor of their preferred samples was just right. Panelists considered the flavor of nectar made from freeze-dried puree to be weak. Sixty-six percent of the population preferred their favored sample rather than the commercial nectar, primarily due to flavor and sweetness differences. Overall, except for the commercial nectar, $71 \%$ of the panelists were either very satisfied or satisfied with the guava products and only 5\% disliked them. The remainder of the panelists expressed a neutral opinion. These results for clear juice products, however, are in contrast to the findings of Askar et al. (1992). They reported a significant loss of quality in clear guava juice and found it unacceptable to consumers. This may be due to a difference in the sensory method used by Askar et al. (1992) or to the more diverse ethnicity of consumers participating in this study.

TABLE 5 .

SENSORY COMPARISON OF GUAVA JUICES PREPARED BY DIFFERENT METHODS

\begin{tabular}{|c|c|c|}
\hline Juice type & $\begin{array}{c}\text { Number of panelists ranking as most } \\
\text { preferred }\end{array}$ & Rank Total' \\
\hline Aseptic guava puree & 32 & $68^{2}$ \\
\hline Pasteurized guava juice & 5 & $121^{\mathrm{b}}$ \\
\hline Freeze-dried clear juice powder & 5 & $130^{\mathrm{b}}$ \\
\hline Freeze-dried guava puree powder & 3 & $131^{\mathrm{b}}$ \\
\hline
\end{tabular}

Means with the same letter are not significantly different at $P<0.05$ using the Basker table and the Friedman test.

\section{CONCLUSIONS}

The commercial enzyme Pectinex Ultra SP-L was successfully applied to guava puree. Enzyme concentration, incubation time and temperature were optimized at $700 \mathrm{ppm}, 1.5 \mathrm{~h}$ and $50 \mathrm{C}$, respectively, resulting in a $51 \%$ reduction in viscosity, $13 \%$ increase in ascorbic acid content and $18 \%$ increase in yield of a clearer juice. The enzyme application also helped to clarify the juice.

In terms of clarity, guava juice prepared using UF was clearer with $89.6 \%$ transmission, as compared to $\mathbf{8 2 . 8 \%}$ for plate and frame filtered juice. However, plate and frame filtered juice retained more soluble solids, contained $5.8 \%$ more ascorbic acid than the UF juice and had higher flux rates at all times.

This was the first reported attempt to produce clarified guava juice powder. Freeze drying produced the best quality guava powder in terms of ascorbic acid and flavor retention, though it was quite hygroscopic in nature. Spray drying 
produced an extremely stable powder at room temperature with a minimum moisture content of $3 \%$. Tunnel drying produced dried flakes that were extremely difficult to remove from trays and difficult to grind. Although the quality of tunnel dried powder was inferior, the addition of maltodextrin resulted in better color retention in the final powder. Because freeze drying is an expensive method to apply commercially, spray drying may be the best alternative for producing guava powder.

Seventy-one percent of consumer sensory panelists most preferred the cloudy juice prepared from aseptic guava puree. However, there was no significant difference among responses for juices prepared from pasteurized, clear nectar, freeze-dried puree powder and freeze-dried, clear juice powder.

\section{ACKNOWLEDGMENTS}

We would like to thank Drs. R. Paul Singh and Thomas Rumsey of the Dept. of Agricultural and Biological Engineering, UC Davis, for technical assistance with this project.

\section{REFERENCES}

ASKAR, A., EL-SAMAHY, S.K. and ABD EL-SALEM, N.A. 1992. Production of instant guava drink powder. Confructa-Studien 36(5-6), 154-161.

BRASIL, I.M., GERALDO, A.M. and RAIMUNDO, W.F. 1995. Physicalchemical changes during extraction and clarification of guava juice. Food Chem. 54(4), 383-386.

CHAN, W.Y. and CHIANG, B.H. 1992. Production of clear guava nectar. Intern. J. Food Sci. Technol. 27, 435-441.

CONSTENLA, D.T. and LOZANO, J.E. 1997. Hollow fibre ultrafiltration of apple juice: Macroscopic approach. J. Food Sci. Technol. 30(4), 373-378.

EL-ZOGHBI, M., EL-SHAMEI, Z. and HABIBA, R. 1992. Effect of enzyme application on some properties of guava puree. Fruit Processing 2(7), 106-108.

Grain Processing Corporation. 1998. Technical Bulletin: Pure Cote Corn Starches in Aqueous Film Coating.

HODGSON, A.S., CHAN, H.T., CAVAlETTO, C.G. and PARERA, C.O. 1990. Physical-chemical characteristics of partially clarified guava juice and concentrate. J. Food Sci. 55(6), 1757-1761. 
IMUNGI, J.K., SCHEFFELDT, P. and SAINT-HILAIRE, P. 1980. Physicochemical changes during extraction of clear guava juice. Lebensm.-Wiss. u.-Technol. 13, 248-251.

JAGTIANI, J., CHAN, H.T. and SAKAI, W.S. 1988. Tropical Fruit Processing, Academic Press, San Diego.

KRAMER, M.E. 1998. Application Scientist, Grain Processing Corp., personal communication.

LAWLESS, H.T. and HEYMANN, H. 1998. Sensory Evaluation of Food: Principles and Practices, Chapman \& Hall and International Thompson Publishing, New York.

MURALIKRISHNA, M., NANJUNDASWAMY, A.M. and SIDDAPPA, G.S. 1969. Guava powder preparation, packaging, and storage studies. J. Food Sci. Technol. 6, 93-98.

Novo Nordisk. 1998. The Production of Clear, Stable Juices and Concentrates: Guidelines for Processing and Quality Control.

SANDHU, K.S. and BHATIA, B.S. 1985. Physico-chemical changes during preparation of fruit juice concentrate. J. Food Sci. Technol. 22, 202-206. STONE, H. and SIDEL, J.L. 1993. Sensory Evaluation Practices, Academic Press, San Diego.

WENKAM, N.S. and MILLER, C.D. 1965. Hawaii Agricultural Research Station, Bulletin 135. 